\title{
Análise de DNA em osso humano: estudo qualitativo da microestrutura do osso compacto
}

\author{
Analysis of human DNA bone: qualitative \\ study of compact bone microstructure
}

\author{
Edna Sadayo Miazato Iwamura'
}

Iwamura ESM. Análise de DNA em osso humano: estudo qualitativo da microestrutura do osso compacto [Resumo]. Saúde, Ética \& Justiça, São Paulo. 2003;8(1/2):60-1.

\begin{abstract}
RESUMO: Para a execução da etapa inicial da identificação médico-legal de restos humanos (antropometria e exame dos arcos dentários), faz-se necessária uma limpeza prévia da ossada, para a remoção de tecidos moles putrefeitos. Os casos não identificados por esses métodos tradicionais, poderão ser submetidos ao exame de DNA. No entanto, apesar do grande avanço da biologia molecular, utilizando a amplificação de DNA pela PCR, algumas limitações que afetam a habilidade de se obter DNA em restos humanos, permanecem. Dessa forma, o objetivo deste trabalho foi fornecer subsídios morfológicos para os analistas forenses, com ênfase na prática médico-legal, visando uma utilização mais eficiente do DNA obtido de osso compacto de restos humanos em decomposição ou já esqueletizados, sem tecidos moles aderidos. Foi realizado o estudo da microestrutura do tecido ósseo compacto femoral, de restos humanos em decomposição, ainda com tecidos moles, que foram limpos pela fervura em água $(n=7)$ e ossadas já esqueletizadas pela decomposição natural, que não foram fervidas $(n=8)$. Destes, seis ossadas foram provenientes de cemitério público regular, após 3 anos de inumação, 1 ossada proveniente da região amazônica, e 1 ossada de origem desconhecida. Estas duas ultimas, apresentado-se porosas ou quebradiças. As análises morfológicas de cortes histológicos foram coradas com hematoxilina e eosina e o DNA amplificado pela PCR para os lociCSF1PO, TPOX, TH01, F13A0, FESFPS, vWA, D16S539, D7S820, D13S317 e amelogenina. Os resultados da análise desses dois grupos foram comparados com os de cadáveres frescos $(n=5)$ do Serviço de Verificação de Óbitos da Capital. A fervura dos ossos, do modo como é realizada no Instituto Médico Legal de São Paulo, pode aumentar a eosinofilia da matriz óssea e, em alguns casos, pode promover a desagregação dos ósteons. Tal procedimento pode remover células, mas pode também remover possíveis inibidores da PCR, favorecendo a análise do DNA obtido destas amostras. O fator limitante para a obtenção e análise de DNA, em amostras de ossos limpos por fervura, é a quantidade exígua de células. Ossos não submetidos à fervura, após inumação por três anos ou há mais tempo em contato com a terra, podem apresentar alterações da microestrutura. No entanto, a presença de hemácias preservadas e núcleos de osteócitos nestas amostras, indica melhor preservação de células em relação às amostras de ossos fervidos. O fator limitante para a análise de DNA nestas amostras é a presença sugestiva de inibidores da reação de amplificação pela PCR. Restos humanos, sem tecidos moles, macroscópicamente não preservados (porosos e quebradiços), e não submetidos à fervura,
\end{abstract}

Tese apresentada a Faculdade de Medicina da Universidade de São Paulo, defesa em 2002.

Endereço para correspondência: Rua Teodoro Sampaio, 115, CEP 05405-000, São Paulo, SP, e-mail:eiwamura @usp.br 
Iwamura ESM. Análise de DNA em osso humano: estudo qualitativo da microestrutura do osso compacto. [Resumo].

apresentam alterações de perda de matriz mineralizada; no entanto, nestas amostras ainda é possível encontrar células preservadas. Os resultados obtidos no neste trabalho permitem traçar algumas estratégias para uma melhor utilização nos protocolos de extração e análise do DNA em osso compacto de restos humanos.

DESCRITORES: DNA/análise. Osso e ossos/patologia. Fêmur/patologia. Reação em cadeia da polimerase/métodos. Técnica de amplificação ao acaso de DNA polimórfico. Antropologia forense/ métodos. Medicina legal.

Iwamura ESM. Analysis of human DNA bone: qualitative study of compact bone microstructure [Abstract]. Saúde, Ética \& Justiça, São Paulo. 2003;8(1/2):60-1.

ABSTRACTS: To the first essential step to forensic identification of human remains (anthropological study of race, sex, age, etc) it is necessary a previous cleaning of the bones, to remove decomposing soft tissues. Medico-legal inconclusive or non identified cases, by using these traditional methods, could be subjected to DNA analysis. However, in spite of advances in human identification techniques, specially by PCR amplified DNA, some limitations that affect the ability to obtain DNA in human remains still persist. Therefore, the aim of this study was to provide additional support from morphological analysis, to help forensic analysts personnel to utilise more efficiently the DNA, extracted from compact bones of human remains in decomposition or already skeletonized corpse, it means without soft tissues, with special emphasis in the legal-medicine practice. Femoral compact bones were obtained from: 7 human remains found on the ground, in different degree of decomposition which were cleaned by boiling to remove soft tissues; also studied were collections of bones from 8 corpses having undergone natural decomposition: 6 human remains exhumed after 3 years from a common public cemetery in São Paulo City; 1 case from amazon region and 1 case with no information, both cases remained from long time (more than 3 years) in contact with soil. All eight cases, were not boiled as no soft tissue were adhered. As a control, five cadavers 12 to 16 hours post mortem were also used. The compact bones histological sections were stained by haematoxilin and eosin and the loci CSF1PO, TPOX, TH01, F13A01,FESFPS, vWA, D16S539, D7S820, D13S317 and amelogenin were amplified by PCR. The procedure for boiling the human remains utilised in the Legal Medicine Institute of São Paulo would have increased the eosinophily of bone matrix and, in some cases, promoted the desaggregation of the osteons. In addition these procedures would have removed the cells, but in some cases would have removed possible inhibitors of the PCR, favouring in this way the analysis of DNA obtained from these samples. The limiting factor to obtain successful analysis in bones submitted to boiling seem to be the low quantity of nuclei present in these samples. For the other hand, in bones not cleaned by boiling, the presence of preserved red cells and oscteocyte nuclei inside the lacunae indicates better preservation of cells in relation to those bones cleaned by boiling. The limiting factor to obtain successful DNA analysis in bones exhumed or in contact of soil, is the suggestive presence of inhibitors of PCR. Porous and brittle bones from human remains, without soft tissues that are not processed by boiling, present alterations through loss of mineralised matrix, although it is still possible to found preserved cells in these samples. The results presented in this work clarify concerns about viability of DNA for identification analysis. They also help to establish better strategies for optimisation of DNA extraction and analysis in compact bones of human remains.

KEY WORDS: DNA/analysis. Bone and bones/pathology. Femur/pathology. Polymerase chain reaction/ methods. Random amplified polymorphic DNA technique. Forensic antropology/methods. Forensic medicine. 